\title{
Fabrication and study of structural, optical features of nano structured, photo-harvesting organo-lead halide-based perovskite solar cell
}

\author{
Abhishek Dhara ${ }^{a}$ Rohit L. Vekariya ${ }^{b, c *}$, Argha Dey ${ }^{a}$, Subhasis Roy ${ }^{a}$ \\ ${ }^{a}$ Department of Chemical Engineering, Rajabazar Science College, University of Calcutta, \\ Kolkata 700009, India. \\ ${ }^{b}$ Department for Management of Science and Technology Development, Ton Duc Thang \\ University, Ho Chi Minh City, Vietnam \\ ${ }^{c}$ Faculty of Applied Sciences, Ton Duc Thang University, Ho Chi Minh City, Vietnam.
}

*Corresponding Author: (Dr. R. L. Vekariya; Email: rohit.vekariya@tdt.edu.vn) 


\begin{abstract}
In a world where conventional sources of energy are fast depleting, the quest for alternative energy sources may hold the key for the survival of humanity. In the present work, emphasis has been given to the idea of producing energy from perovskite based solar cells. In order to bring this idea into fruition, a unique and novel nano structured perovskite material $n$-propyl ammonium lead chloride $\left(\mathrm{C}_{3} \mathrm{H}_{7} \mathrm{NH}_{3}{ }^{+} \mathrm{PbCl}_{3}{ }^{-}\right)$was prepared through a unique co-precipitation route using $n$-propyl amine $\left(n-\mathrm{C}_{3} \mathrm{H}_{7} \mathrm{NH}_{2}\right)$ and hydrochloric acid as the starting precursors with aqueous solution of $\mathrm{Pb}\left(\mathrm{CH}_{3} \mathrm{COO}\right)_{2} 3 \mathrm{H}_{2} \mathrm{O}$. Finally acetic acid was added to the solution and this solution was allowed to concentrate and then gradually cooled down to room temperature. After math, the synthesized material was spin-coated on $\mathrm{TiO}_{2}$ film to fabricate the solar cell. The device was then undergone systematic analysis using XRD, SEM, UV and Photo Conversion to get a transparent idea regarding its structural, electrical and optical properties. When experimentally applied, this perovskite-based solar cell has shown energy conversion efficiency $(\eta)$ of around $6.01 \%$ which is noticeably good. Thus it can be concluded that this material is promising for fabrication of vastly efficient solar cells. This technology can be tried in large scale as an alternative of conventional energy in the near future.
\end{abstract}

Keywords: Perovskite materials; energy; band-gap; photo-efficiency. 


\section{Introduction}

Keeping the exponential growth of world population in mind, it is only natural to predict that the demand for energy will only go up [1]. It can never be denied that energy is the key driving force for the advancement in human living standards and hence, in coming years the worldwide energy consumption is expected to be double [2,3]. Since 1991, Solar Cells have received much attention as a prime example of next generation photovoltaic devices [4-8]. As of now, the efficiency of dye-sensitized solar cells (DSSCs) and perovskite solar cells (PSCs) have reached $\sim 20 \%$ of efficiency $[9,10]$. Although the performance of certain PSCs, fabricated by different groups with one-step techniques, has reached $\sim 18 \%-20 \%$ efficiency, it is normally $\sim 15 \%-16 \%$ for most laboratories because of the aforesaid reasons [11-14]. Despite of high efficiency in DSSC, the commercialization of the same has been hindered due to the chief issues related to instability-factor, leakage of liquid electrolytes etc. [15-19]. Consequently, DSSCs possessing organic hole transfer material (HTM) have drawn greater focus due to their stability [20] and comparable efficiency [21]. For hybrid perovskite solar cells, long-term stability may be attained in future works [22]. Besides the factor of higher efficiency, this stability factor is the key reason for scientists to concentrate on the fabrication of perovskite based solar cells. Perovskite layers with smooth surface morphology, large grain sizes are helpful to obtain higher efficiency $[23,24]$. As film non uniformity is reduced in large-area PSCs, modified surface planarity is required in order to minimize energy loss in weak links [25,26].

Presently nano structured semiconductor materials impregnated in solar cells are widely gone through due to their favorable performance as these materials can surge the absorption capability [27]. This nano phot -materials also have the benefit of stability due to their intrinsic dipole moments and high extinction co-efficient as well [28]. Besides, appropriate nano morphology 
can uplift the charge-carrier transport inside the participating layers of the material. Solar radiation is directly used to generate electricity in facile way to channelize the renewable energy flow via electrochemical devices $[29,30]$. It is also beneficial because power can be generated at the users' place. Different types of photovoltaic devices, such as thin film solar cells, crystalline silicone, semiconductor based solar cells, organic-inorganic hybrid (Perovskite) solar cells, DSSCs and bulk hetero junction solar cells are used world-wide [31,32]. Among all the devices, the PSCs and DSSCs have been regarded as potential contenders for power-generation. Organic sensitizers and solid electrolytes or HTM are the building unit of the DSSC and perovskite hybrid nano materials are the hearts of the PSCs [33].

A lot of working systems have been generated by using perovskite material methyl ammonium lead chloride as the basic unit of solar cell [33-35]. In one [3] of our previous works, we have used ethyl ammonium lead chloride effectively as the basic unit of perovskite solar cell. But there is no notable evidence of making solar cell using the perovskite material $n$-propyl ammonium lead chloride $\left(n-\mathrm{C}_{3} \mathrm{H}_{7} \mathrm{NH}_{3} \mathrm{PbCl}_{3}\right)$. In the present work, we have synthesized nano structured n-propyl ammonium lead chloride deposited on $\mathrm{TiO}_{2}$ film for fabrication of the solar cell. We have used SEM analysis in order to study the surface-morphology of the synthesized material. We have performed XRD to reveal the crystalinity of the synthesized material. UVspectra and calculation of Photo conversion efficiencies were done to get a proper view regarding the optical and electrical properties of the cell respectively. Our synthesized photoactive, perovskite material is completely unique and novel as no previous references of this material have been found as per our literature-survey. 


\section{Materials and methods}

Lead (II) acetate $\left[\mathrm{Pb}\left(\mathrm{CH}_{3} \mathrm{COO}\right)_{2} 3 \mathrm{H}_{2} \mathrm{O}\right]$ purity $99.99 \%$, hydrochloric acid (purity 99\%) and $n$-propylamine (purity 99\%) for the precursor solution of $n-\mathrm{C}_{3} \mathrm{H}_{7} \mathrm{NH}_{3} \mathrm{PbCl}_{3}$ were bought from Sigma-Aldrich, India. The components which had been used in the preparation of the $\mathrm{TiO}_{2}$ solgel films are given below: Titanium isopropoxide (TIP) (Ti[OCH(CH3 $\left.)_{2}\right]_{4}$ purity 99\%), ethanol $\left(\mathrm{CH}_{3} \mathrm{CH}_{2} \mathrm{OH}\right.$, purity $\left.99.9 \%\right)$ and acetic acid $\left(\mathrm{CH}_{3} \mathrm{COOH}\right.$, purity $\left.99.5 \%\right)$. All these were purchased from Sigma-Aldrich, India. Glass slide coated with transparent, conducting fluorine doped tin oxide (FTO) was used as substrate.

\section{Fabrication of perovskite solar cell}

Sol-gel spin-coating method was used to prepare $\mathrm{TiO}_{2}$ thin film. Firstly, a mixture of $5 \mathrm{ml}$ of acetic acid solution and $50 \mathrm{ml}$ of ethanol was stirred for $5 \mathrm{~min}$ in magnetic-stirrer. Then $6.8 \mathrm{ml}$ of Titanium isopropoxide was added by pipette to the beaker containing the stirred mixture of acetic acid and ethanol. The mixture underwent continuous stirring and for a further two minutes after addition of the precursor. Finally, $\mathrm{TiO}_{2}$ solution was prepared [3,22,29]. Thin film of $\mathrm{TiO}_{2}$ was spin-coated using a standard photoresist spinner [Model: 10 MLH Plus, REMI make] at 2000 rpm for 3 minutes on the FTO glass slide which was pre-cleaned by detergent solution, water and ethanol in an ultrasonic bath. Then the glass slide was sintered at $450{ }^{\circ} \mathrm{C}$ for $45 \mathrm{~min}$.

$n$-Propyl amine solution and conc. hydrochloric acid were mixed in 1:3 volume ratio. After stirring the mixture at $95^{\circ} \mathrm{C}$ for about one hr, required amount of aqueous solution of lead acetate was added drop wise into the mixture. Calculated amount of acetic acid was added after appearance of a white precipitation. Aftermath, the solution was concentrated to saturation and cooled down to room temperature. Thus, Perovskite n-propyl ammonium lead chloride was 
prepared $[3,22,29]$. Finally, fabricated Perovskite material was spin coated at $2500 \mathrm{rpm}$ for 30 sec on the $\mathrm{TiO}_{2}$ layer over the FTO glass. Then again the FTO glass was heated at $90{ }^{\circ} \mathrm{C}$ for 20 min and settled to cool down gradually.

\section{Results and discussion}

\section{Microstructure analysis}

The microstructure analysis of the materials has been carried out using Scanning Electron Microscope (SEM) micrograph [Model: EVO 18 Special Edition, ZEISS make]. Fig. 1 and Fig. 2 display the SEM pictures of pure $n$-propyl ammonium lead chloride and $n$-propyl ammonium lead chloride deposited on $\mathrm{TiO}_{2}$ layer respectively.

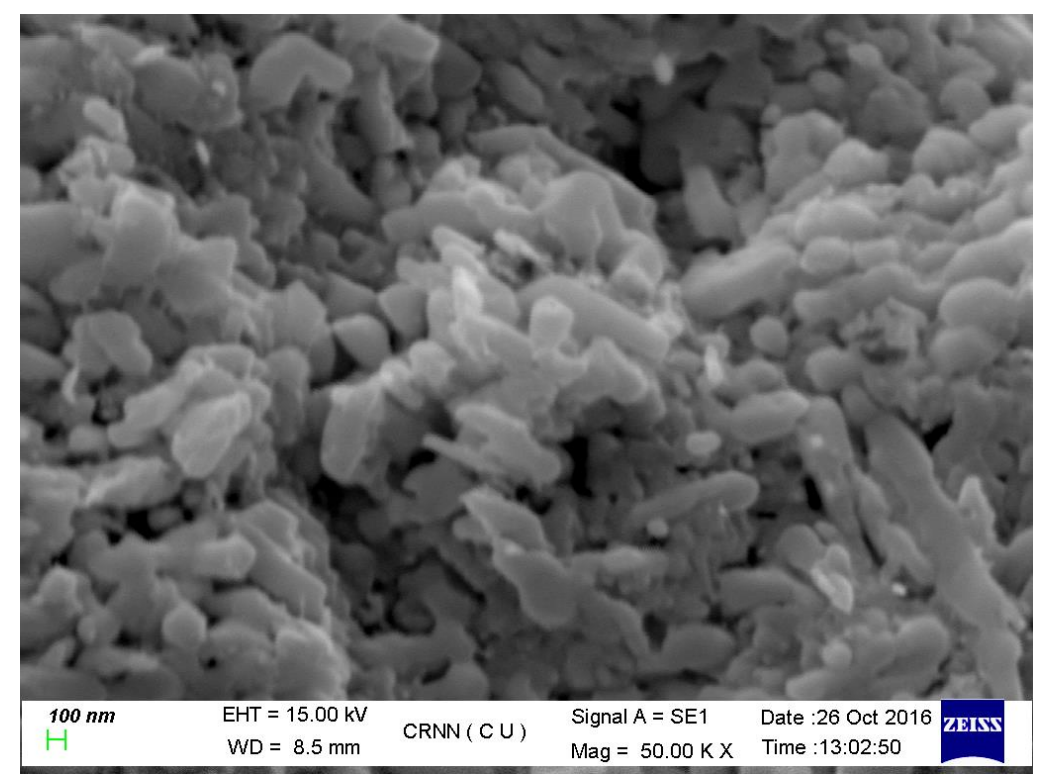

Fig. $1 \mathrm{SEM}$ image of $n-\mathrm{C}_{3} \mathrm{H}_{7} \mathrm{NH}_{3} \mathrm{PbCl}_{3}$ without $\mathrm{TiO}_{2}$ displays its smaller grain size

Fig. 1 represents large grain-size of $n$-propyl ammonium lead chloride. After deposition on $\mathrm{TiO}_{2}$ layer, an appreciable morphological change of the material happened along with significant change in the grain structure of n-propyl ammonium lead chloride. The surface becomes uniform 
and the grain size becomes larger (around $50 \mathrm{~nm}$ ) and more or less uniformly columnar-shaped. Perhaps, competition among the growth fronts from neighboring nucleation centers (Fig. 2) $[18,20]$ results this tilted-alignment.

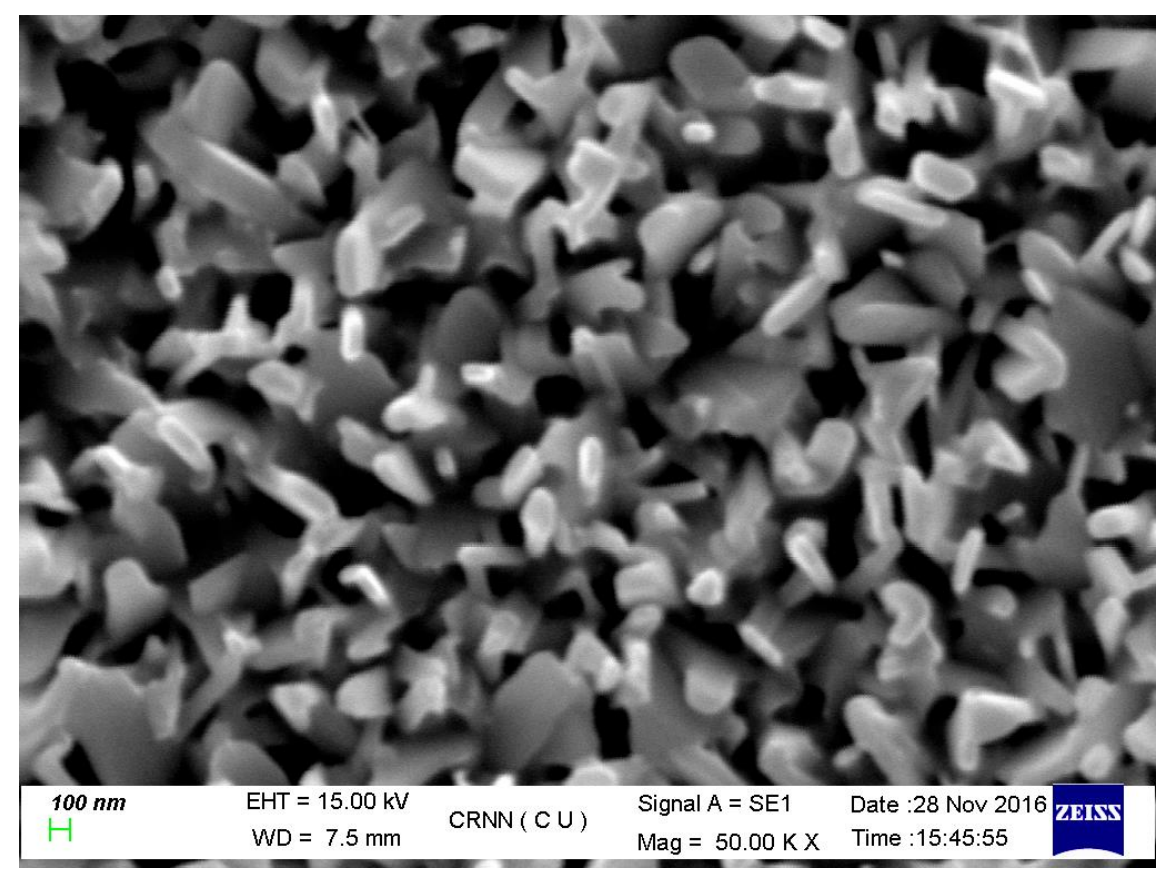

Fig. 2 SEM image of $n-\mathrm{C}_{3} \mathrm{H}_{7} \mathrm{NH}_{3} \mathrm{PbCl}_{3}$ with $\mathrm{TiO}_{2}$ represents its columnar-shaped grain structure

The surface of $n$-propyl ammonium lead chloride becomes smoother and highly uniform when it is deposited on $\mathrm{TiO}_{2}$ layer. The pores on the surface of $n$-propyl ammonium lead chloride deposited on $\mathrm{TiO}_{2}$ layer are bit smaller. Quite large grain-size of $n$-propyl ammonium lead chloride deposited on $\mathrm{TiO}_{2}$ layer makes this material highly polarisable and it results its higher photo-efficiency. The uniform pores help to uniform flow of electrons through the material. The n-propyl ammonium lead chloride deposited on $\mathrm{TiO}_{2}$ layer is nano structured and these nano structured perovskite grains can capture sunlight in higher extent due to quite high surface to volume ratio and absorbs more photon energy [25]. The nano-material excites more and generates much excitons making the perovskite material an effective photo active matter [36,37]. 


\section{XRD Analysis}

The degree of crystallinity affects charge transport of a material. This parameter of the synthesized perovskite material n- propyl ammonium lead chloride was determined by using Xray diffraction patterns on an XRD analyzer [Model: Miniflex - ZD06184, Rigaku make], equipped with a graphite mono chromator and working with $\mathrm{CuK} \alpha(\lambda=1.54 \AA)$. Fig. 3 represents the XRD pattern of the thin film, that clearly shows that the material possesses a crystalline nature.

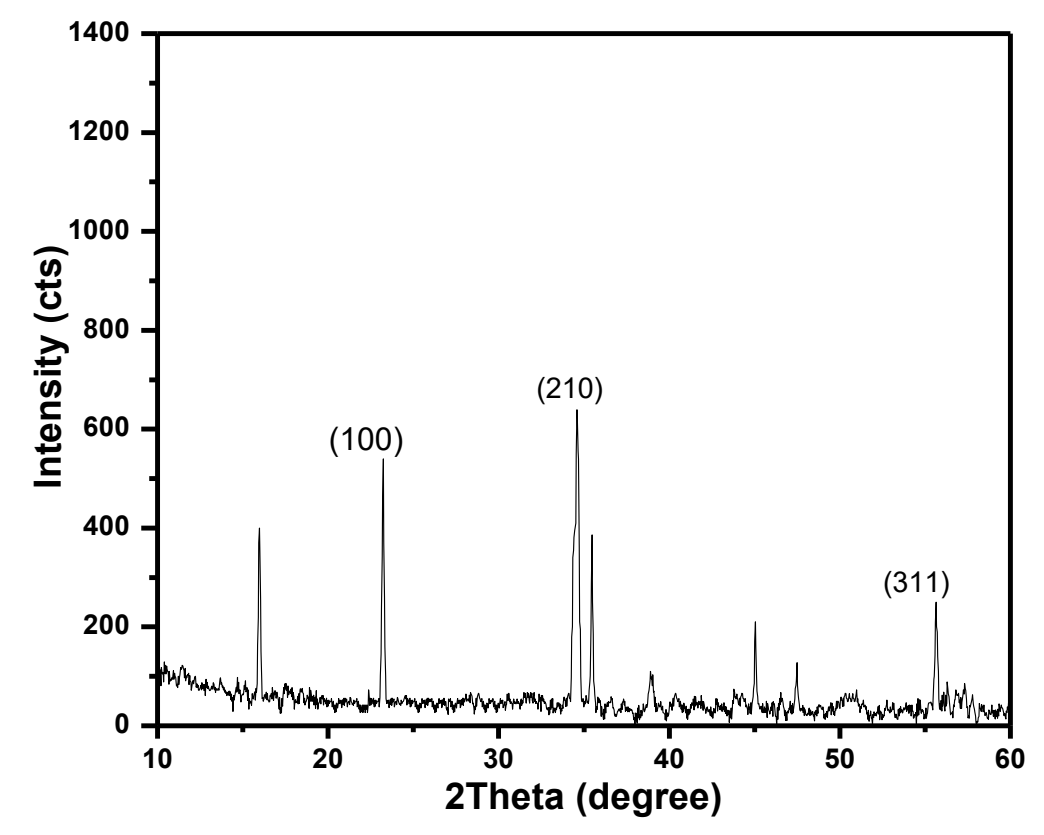

Fig. 3 XRD pattern of the perovskite material $n-\mathrm{C}_{3} \mathrm{H}_{7} \mathrm{NH}_{3} \mathrm{PbCl}_{3}$

The characteristic peaks at $23^{\circ}, 34^{\circ}$ and $55^{\circ}$ corresponding to the (100), (210) and (311) planes of tetragonal perovskite ethyl ammonium lead chloride layer confirm its structure $[3,22,38]$. The depression of (311) plane happens perhaps due to higher extent of crystal defects present in the bulky matter. 


\section{UV-vis. spectroscopy}

The study of the interaction of light with semiconducting material caters basic information regarding further photo-applicability of the material. Here, the UV-vis. spectroscopy [Model: U4100 Spectrophotometer, Hitachi make] was performed for two materials to get an over-view about the light sensitive property of them. The UV vis. spectra (Fig. 4) of $n-\mathrm{C}_{3} \mathrm{H}_{7} \mathrm{NH}_{3} \mathrm{PbCl}_{3}$ perovskite with and without $\mathrm{TiO}_{2} /$ glass substrates show a gradual change of color.

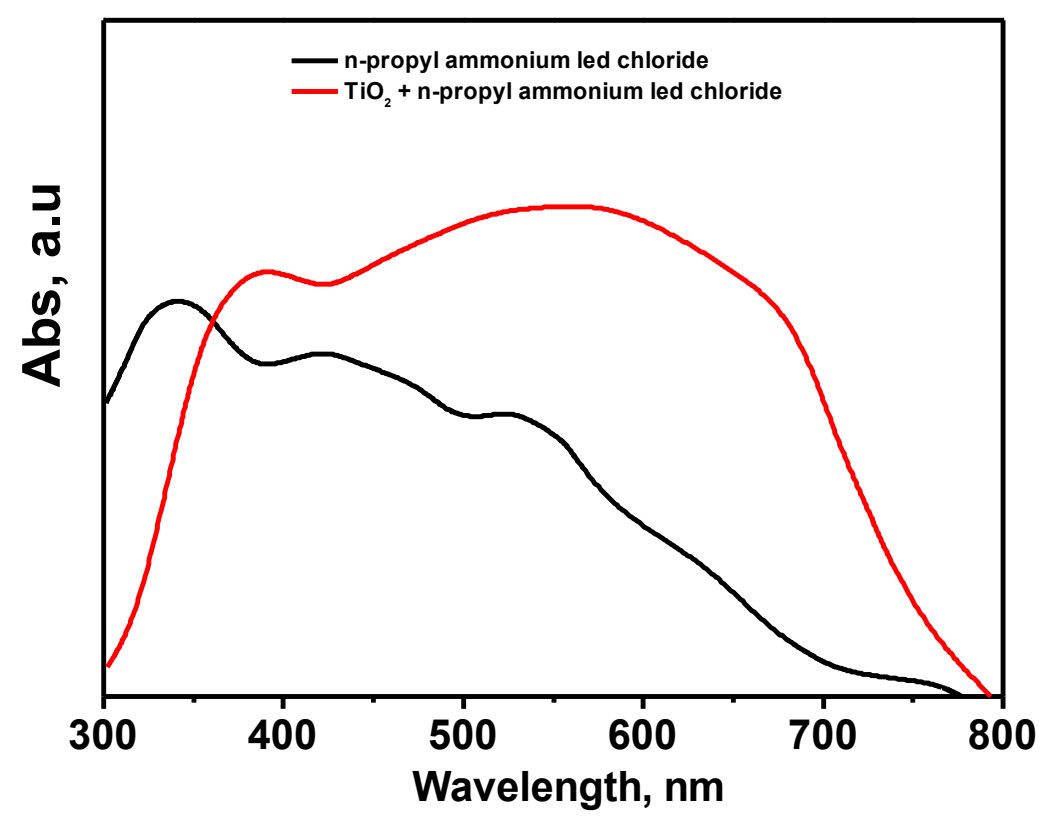

Fig. 4 UV-vis spectra of $n$-propyl ammonium lead chloride without $\mathrm{TiO}_{2}$ and $n$-propyl ammonium lead chloride deposited on $\mathrm{TiO}_{2}$ and band gap calculation of $n$-propyl ammonium lead chloride without $\mathrm{TiO}_{2}$ and $n$-propyl ammonium lead chloride deposited on $\mathrm{TiO}_{2}$.

An overall increase in intensity of the spectrum has happened when $n-\mathrm{C}_{3} \mathrm{H}_{7} \mathrm{NH}_{3} \mathrm{PbCl}_{3}$ coated on $\mathrm{TiO}_{2}$ and it covers large range of spectrum $(340$ to $785 \mathrm{~nm})$. It indicates the proper arrangement of the perovskite material $n-\mathrm{C}_{3} \mathrm{H}_{7} \mathrm{NH}_{3} \mathrm{PbCl}_{3}$ on the surface of $\mathrm{TiO}_{2}$ and results good absorbance [25]. Moreover, mathematical calculation shows that the band gap of pure $n-\mathrm{C}_{3} \mathrm{H}_{7} \mathrm{NH}_{3} \mathrm{PbCl}_{3}$ is $1.72 \mathrm{eV}$, which is good enough to show good photo-efficiency and that of the material on $\mathrm{TiO}_{2}$ 
surface is $1.50 \mathrm{eV}$. It proves that $\mathrm{TiO}_{2}$ surface coating beneath the Perovskite material makes a change in its flat band potential and makes the material more photo-effective [3,32]. The higher crystal-defects of large propyl group and its positive inductive effect help to make the band-gap of the perovskite material on $\mathrm{TiO}_{2}$ - surface optimally low $[31,39]$. The working principle of the fabricated solar cell is displayed in the following schematic illustration (Fig. 5).

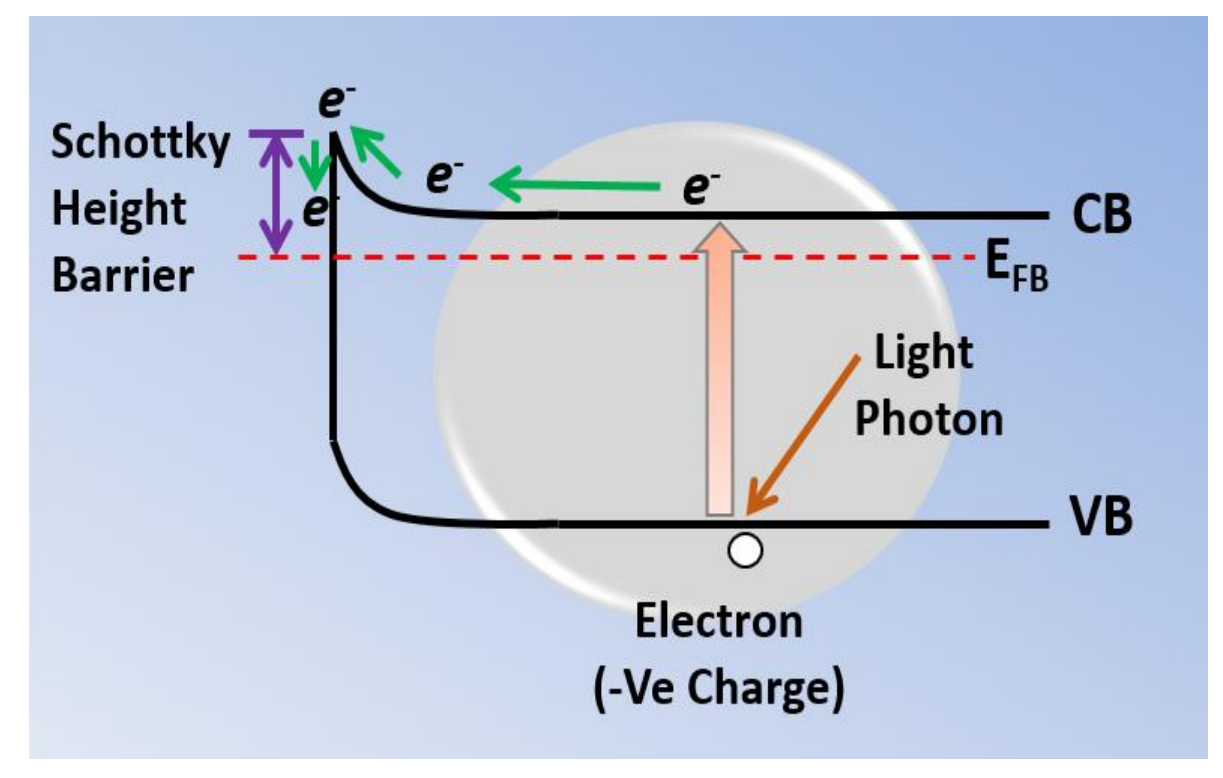

Fig. 5 The schematic representation of the working principle of the fabricated solar cell.

\section{Photovoltaic performance}

The current density-voltage $(J-V)$ measurement was performed under AM1.5G standard illumination $\left(100 \mathrm{mWcm}^{-2}\right)$. The $J-V$ parameters of the characterized photovoltaic devices are shown in Fig. $\mathbf{6}$ and the equivalent data are presented in Table 1. 


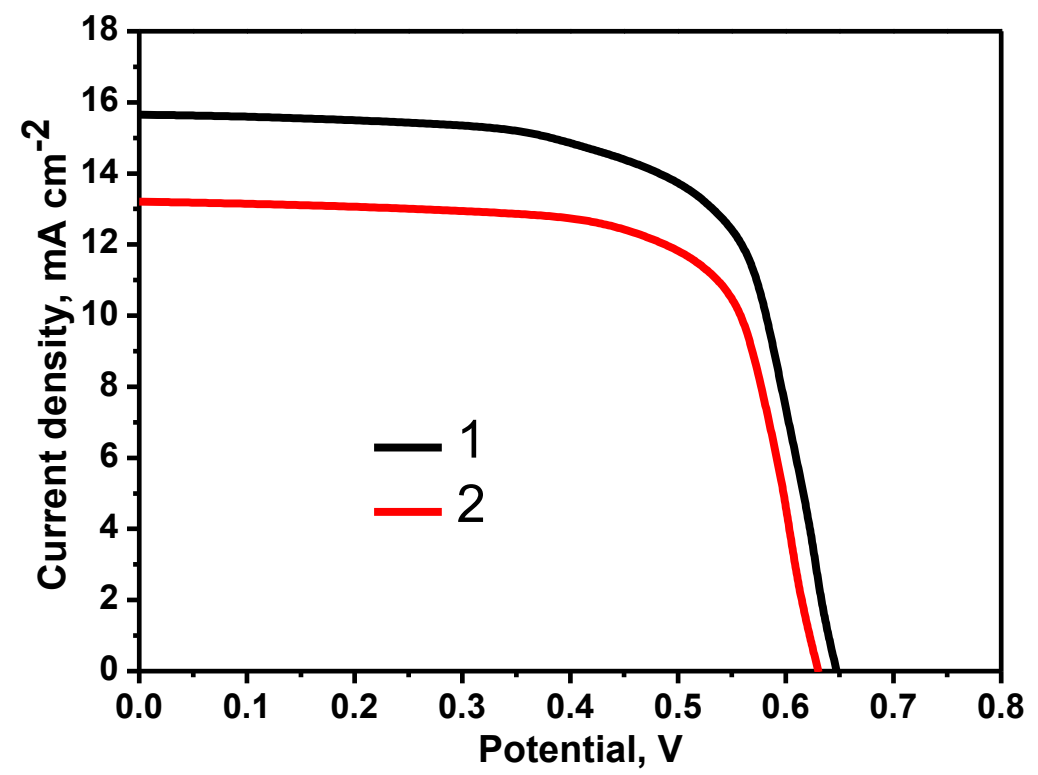

Fig. 6 The $J-V$ characterization of $n-\mathrm{C}_{3} \mathrm{H}_{7} \mathrm{NH}_{3} \mathrm{PbCl}_{3}$ coated on $\mathrm{TiO}_{2}$ (1) and $n-\mathrm{C}_{3} \mathrm{H}_{7} \mathrm{NH}_{3} \mathrm{PbCl}_{3}$ coated on $\mathrm{TiO}_{2}$ (2) carried out under AM $1.5 \mathrm{G}$ illuminations $\left(100 \mathrm{~mW} \mathrm{~cm} \mathrm{~cm}^{-2}\right)$.

Here, our focus was on the comparison between the newly developed $n$-propyl ammonium lead chloride deposited on $\mathrm{TiO}_{2}$ with a reported very house-hold perovskite material which is methyl ammonium lead chloride deposited on $\mathrm{TiO}_{2}$. The ratio of the maximum power from the solar cell to the product of $V_{o c}$ and $I_{s c}$ is referred as fill factor (FF).

Table 1. Photovoltaic parameters produced from $J-V$ performance of two types of photo devices under AM1.5G standard illumination $\left(100 \mathrm{mWcm}^{-2}\right)$. The illuminated areas of all devices were 5 $\mathrm{cm}^{2}$.

\begin{tabular}{lcccc}
\hline Materials & $\mathbf{J}_{\text {sc }}$ & $\mathbf{V}_{\text {oc }}$ & FF (\%) & 廿\% \\
& $(\mathbf{m A ~ c m})^{-2}$ & $(\mathbf{V})$ & & \\
& $14.2 \pm(0.3)$ & $0.617 \pm(0.02)$ & $68.2 \pm(1.0)$ & $6.01 \pm(0.30)$ \\
\hline$\left(n-\mathrm{C}_{3} \mathrm{H}_{7} \mathrm{NH}_{3} \mathrm{PbCl}_{3}\right.$ on $\left.\mathrm{TiO}_{2}\right)$ & $11.0 \pm(0.3)$ & $0.535 \pm(0.05)$ & $64.2 \pm(0.9)$ & $4.3 \pm(0.40)$ \\
$\left(\mathrm{CH}_{3} \mathrm{NH}_{3} \mathrm{PbCl}_{3}\right.$ on $\left.\mathrm{TiO}_{2}\right)$ & & & & \\
\hline
\end{tabular}


The "squareness" of the solar cell graphically represents the FF and it is actually the area of the largest rectangle which will fit in the IV curve. The FF of our fabricated solar cell is quite appreciable. The result presented in Table.1 confirms that the newly developed perovskite material n-propyl ammonium lead chloride deposited on $\mathrm{TiO}_{2}$ surface shows higher photo conversion efficiency $(\eta)$ than its previously reported methyl analogue [24,27,33] and ethyl analogue [3]. Greater extent of crystal defects present in the highly bulky $n$-propyl ammonium lead chloride is one probable factor behind its better photo-efficiency than its methyl analogue. Due to larger sized $n$-propyl group, propyl ammonium lead chloride has higher polarisibility than methyl ammonium lead chloride and ethyl ammonium lead chloride. This factor and the higher positive inductive effect of $n$-propyl group help in the better performance of the $n$-propyl ammonium lead chloride [20].

\section{Conclusions}

Through the spin coating of the solution obtained from the aqueous mixture of the reagents Lead (II) acetate, hydrochloric acid and $n$-propylamine, $n$-propyl ammonium lead chloride based thin film solar cell was fabricated successfully. The Morphological study has revealed that the thin films contain larger nano-sized particle grains (around $50 \mathrm{~nm}$ ). XRD of the material has indicated required phase formation within it. The outcome of UV-vis. spectra showed that the synthesized material $n-\mathrm{C}_{3} \mathrm{H}_{7} \mathrm{NH}_{3} \mathrm{PbCl}_{3}$ coated on $\mathrm{TiO}_{2}$ possessed band gap energy of around $1.50 \mathrm{eV}$. Then the photovoltaic performance of the fabricated solar cell using the synthesized material $n-\mathrm{C}_{3} \mathrm{H}_{7} \mathrm{NH}_{3} \mathrm{PbCl}_{3}$ coated on $\mathrm{TiO}_{2}$ was tested. The value of the efficiency was around 
$6.01 \%$. This appreciable efficiency enhances the possibility to use the fabricated nano-structured substance as a very efficient solar cell material in industrial scale in the coming days.

\section{Acknowledgements}

Dr. Rohit L. Vekariya is thankful to Ton Duc Thang University (TDTU-DEMASTED) for financial support.

\section{Conflict of interest}

Author declares there is no conflict of interest regarding this publication. 


\section{References}

[1] Kazim S, Nazeeruddin MK, Gratzel M, Ahmad S (2014) Perovskite as Light Harvester: A Game Changer in Photovoltaics. Angew Chem Int Ed 53:2812-2824

[2] Jiandong F, Baohua J, Min G (2014) Perovskite-based low-cost and high-efficiency hybrid halide solar cells. Photonics Res 2:111-120

[3] Dhar A, Dey A, Maiti P, Paul PK, Roy S, Paul S, Vekariya RL (2017) Fabrication and characterization of next generation nano-structured organo-lead halide-based perovskite solar cell. Ionics https://doi.org/10.1007/s11581-017-2256-X

[4] Vekariya RL, Vaghasiya JV, Dhar A (2017) Coumarin based sensitizers with ortho-halides substituted phenylene spacer for dye sensitized solar cells. Organic Electronics 48:291-297

[5] Dhar A, Kumar NS, Paul PK, Roy S, Vekariya RL (2018) Influence of tagging thiophene bridge unit on optical and electrochemical properties of coumarin based dyes for DSSCs with theoretical insight. Organic Electronics 53:280-286

[6] Vekariya RL, Dhar A, Lunagariya J (2017) Doping effect of aminopyridine analogous in supramolecular quasi-solid polymer electrolyte for DSSCs: improvement in ionic diffusion leading to superior efficiency. Ionics DOI 10.1007/s11581-017-2262-z

[7] Vekariya RL, Dhar A, Paul PK, Roy S (2018) An overview of engineered porous material for energy applications: a mini-review. Ionics 24:1-17

[8] Guo F, Liu X, Ding Y, Kong F, Chen W, Zhou L, Dai S (2016) Broad spectral-response organic D-A- $\pi-A$ sensitizer with pyridine-diketopyrrolopyrrole unit for dye-sensitized solar cells. RSC Adv 6:13433-13441 
[9] Lunagariya J, Dhar A, Vekariya RL (2017) Efficient esterification of $n$-butanol with acetic acid catalyzed by the Brönsted acidic ionic liquids: influence of acidity. RSC Adv 7:54125420

[10] Brennan LJ, Barwich ST, Satti A, Faure A, Gunko YK (2013) Graphene-ionic liquid electrolytes for dye sensitised solar cells. J Mater Chem A 1:8379-8384

[11] Lim SP, Lim YS, Pandikumar A, Lim HN, Ng YN, Ramaraj R, Sheng Bien DC, Abou-Zied OK, Huang NM (2017) Gold-silver@ $\mathrm{TiO}_{2}$ nanocomposite-modified plasmonic photoanodes for higher efficiency dye-sensitized solar cells. Phys Chem Chem Phys 19:1395-1407

[12] Maragani R, Misra R, Roy MS, Singh MK, Sharma GD (2017) (D- $\pi-A)_{2}-\pi-D-A$ type ferrocenyl bisthiazole linked triphenylamine based molecular systems for DSSC: synthesis, experimental and theoretical performance studies. Phys Chem Chem Phys 19:8925-8933

[13] Chander N, Khan AF, Komarala VK (2015) Improved stability and enhanced efficiency of dye sensitized solar cells by using europium doped yttrium vanadate down-shifting nanophosphor. RSC Adv 5:66057-66066

[14] Gao P, Gratzel M, Nazeeruddin MK (2014) Organohalide lead perovskites for photovoltaic applications. Energy Environ Sci 7:2448-2463

[15] Xiao Z, Dong Q, Bi C, Shao Y, Yuan Y, Huang J (2014) Solvent Annealing of PerovskiteInduced Crystal Growth for Photovoltaic-Device Efficiency Enhancement. Adv Mater 26:6503-6509 
[16] Yang M, Zhang T, Schulz P, Li Z, Li G, Kim DH, Guo N, Berry JJ, Zhu K, Zhao Y (2016) Facile fabrication of large-grain $\mathrm{CH}_{3} \mathrm{NH}_{3} \mathrm{PbI}_{3}-\mathrm{xBr}_{\mathrm{x}}$ films for high-efficiency solar cells via $\mathrm{CH}_{3} \mathrm{NH}_{3} \mathrm{Br}$-selective Ostwald ripening. Nat Commun 7:12305

[17] Wei Z, Chen H, Yan K, Yang S (2014) Inkjet printing and instant chemical transformation of a $\mathrm{CH}_{3} \mathrm{NH}_{3} \mathrm{PbI}_{3} /$ nanocarbon electrode and interface for planar perovskite solar cells. Angew Chem Int Ed 53:13239-13243

[18] You J, Hong Z, Yang Y, Chen Q, Cai M, Song TB, Chen CC, Lu S, Liu Y, Zhou H, Yang Y (2014) Low-temperature solution-processed perovskite solar cells with high efficiency and flexibility. ACS Nano 8:1674-1680

[19] Docampo P, Ball JM, Darwich M, Eperon GE, Snaith HJ (2013) Efficient organometal trihalide perovskite planar-hetero junction solar cells on flexible polymer substrates. Nat Commun 4:2761-2766

[20] Li Y, Zhang Y, Y. Ma, T. Ren, L. Wang, J. Zhang. Effects of $\pi$-conjugation on electrochemical properties within hole-transporting materials for perovskite solar cells from first principle and molecular dynamics. Organic Electronics 43 (2017) 96-104.

[21] Curiel D, Montoya MM, Hummert M, Riede M, Leo K (2015) Doped-carbazolocarbazoles as hole transporting materials in small molecule solar cells with different architectures. Organic Electronics 17:28-32

[22] Lotsch BV (2014) New light on an old story: perovskites go solar. Angew Chem Int Ed $53: 635-637$ 
[23] Stranks SD, Eperon GE, Grancini G, Menelaou C, Alcocer MJP, Leijtens T, Herz LM, Petrozza A, Snaith HJ (2013) Electron-hole diffusion lengths exceeding 1 micrometer in an organometal trihalide perovskite absorber. Science 342:341-344

[24] Xing G, Mathews N, Sun S, Lim SS, Lam YM, Gratzel M, Mhaisalkar S, Sum TC (2013) Long-range balanced electron- and hole-transport lengths in organic-inorganic $\mathrm{CH}_{3} \mathrm{NH}_{3} \mathrm{PbI}_{3}$. Science 342:344-347

[25] Wehrenfennig C, Eperon GE, Johnston MB, Snaith HJ, Herz LM (2014) High charge carrier mobilities and lifetimes in organolead trihalide perovskites. Adv Mater 26:1584-1589

[26] Burschka J, Pellet N, Moon SJ, Humphry-Baker R, Gao P, Nazeeruddin MK, Gratzel M (2013) Nature 499:316-319

[27] Green MA, Baillie AH, Snaith HJ (2014) Perovskite solar cells with a planar heterojunction structure prepared using room-temperature solution processing techniques. Nat Photonics $8: 133-138$

[28] Jeon NJ, Noh JH, YangWS, Kim YC, Ryu S, Seo J, Seok SI (2015) Compositional engineering of perovskite materials for high performance solar cells. Nature 517:476-480

[29] Kim HS, Lee CR, Im JH, Lee KB, Moehl T, Marchioro A, Moon SJ, Baker RH,Yum JH, Moser JE, Gratzel M, Park NG (2012) Lead iodide perovskite sensitized all-aolidstatesubmicron thin film mesoscopic solar cell with efficiency exceeding 9\%. Sci Rep 2:591

[30] Lee MM, Teuscher J, Miyasaka T,Murakami TN, Snaith HJ (2012) Efficient hybrid solar cells based on meso-superstructured organometal halide perovskites. Science 338:643-647 
[31] Borriello I, Cantele G, Ninno D (2008) Ab initio investigation of hybrid organic inorganic perovskites based on tin halides. Phys Rev B 77:235214

[32] Kagan CR, Mitzi DB, Dimitrakopoulos CD (1999) Organic-inorganic hybrid materials as semiconducting channels in thin-film field-effect transistors. Science 286:945-947

[33] Liang PW, Liao CY, Chueh CC, Zuo F, Williams ST, Xin XK, Lin J, Jen AK (2014) Additive enhanced crystallization of solution processed perovskite for highly efficient planar-hetero junction solar cells. Adv Mater 26:3748-3754

[34] Zhang Q, Liu X (2012) Dye-sensitized solar cell goes solid. Small 8:3711-3713

[35] Mitzi DB (1999) Synthesis, structure, and properties of organic-inorganic perovskites and related materials. Prog Inorg Chem 48:1-121

[36] Wang JTW, Ball JM, Barea EM, Abate A, Alexander-Webber JA, Huang J, Saliba M, Mora-Sero IN, Bisquert J, Snaith HJ (2014) Low-temperature processed electron collection layers of Graphene/ $\mathrm{TiO}_{2}$ nanocomposites in thin film perovskite solar cells. Nano Lett $14: 724-730$

[37] Chiarella F, Zappettini A, Licci F, Borriello I, Cantele G, Ninno D, Cassinese A, Vaglio R (2008) Combined experimental and theoretical investigation of optical, structural and electronic properties of $\mathrm{CH}_{3} \mathrm{NH}_{3} \mathrm{SnX}_{3}$ thin films $(\mathrm{X}=\mathrm{Cl}$, Br). Phys Rev B 77:0451294-10451294-6

[38] Borriello I, Cantele G, Ninno D (2008) Ab initio investigation of hybrid organic inorganic perovskites based on tin halides. Phys Rev B 77:235214 
[39] Yang S, Fu W, Zhang Z, Chen H, Zhe-Li C (2017) Recent advances in perovskite solar cells: efficiency, stability and lead-free perovskite. J. Mater Chem. A: 5:11462-11482 